\title{
Make It Funky: Fela Kuti, James Brown and the Invention of Afrobeat
}

\section{Alexander Stewart}

Evoking the image of ships and black sailors navigating the Atlantic, Paul Gilroy's heuristic stresses dynamic cultural exchange among diverse populations of the African diaspora and the mother continent itself - the "black Atlantic." Gilroy argues for the central role of black musical expression in producing a "distinctive counterculture of modernity" on a basis of shared oppression, common goals, and hybrid cultures (Gilroy, 1993, 36). While the perspective of black Americans' discovery and cultivation of African cultures and sensibilities (both historical and imagined) is more familiar to those on this side of the Atlantic, this process also figured importantly on the African continent. During the early postcolonial years, the interest of African Americans in discovering their African roots stimulated a similar impulse in some Africans. Describing the epiphany brought on by his 1969 trip to the United States, Fela Anikulapo Kuti, the originator of the jazz, funk, and soul-infused genre Afrobeat, recalled:

It was incredible how my head was turned. Everything fell into place, man. . . . For the first time, I saw the essence of blackism [black nationalism]. It's crazy; in the United States people think the black-power movement drew inspiration from Africa. All these Americans come over here looking for awareness. They don't realize they're the ones who've got it over there. Why we were even ashamed to go around in na- 
tional dress until we saw pictures of blacks wearing dashikis on 125th Street. (Darnton, 1977, 6)

In West African popular music an important shift occurred as many musicians looked less to Europe and, by extension, its former colonies in the $\mathrm{Ca}$ ribbean, and began to draw inspiration from African American cultures in the United States. This essay examines Fela's seemingly paradoxical adoption and assimilation of American funk grooves and musical practices in his quest to further Africanize his music, and his transformation from British-trained Nigerian jazz trumpeter to black-nationalist countercultural dissident icon.

\section{From Palmwine and Highlife to Afrobeat and Beyond}

With its proximity to maritime commerce and overland trade routes connected to North Africa and the continent's interior, West Africa has long been a cultural crossroads and nexus of musical development. As noted by Waterman, the interwar years were a particularly fertile period for "the growth of panWest African urban musical traditions [as] traders attempting to extend their networks, sailors manning the large vessels operated by European lines, . . . and other Africans in search of employment" moved back and forth among colonial entrepôts (Waterman, 1990, 48). Since its introduction by Europeans in the late 1800s, the guitar figured importantly in many of these traditions. The most widespread and influential of these guitar-based genres, palmwine music, swept the region during the 1920s and 1930s. Eponymous with the intoxicating beverage whose consumption it accompanied (and that often was used as a form of payment to the musicians), palmwine was most often heard at informal gatherings among the urban lower classes. Accompanying themselves with guitars and percussion tapped on beer bottles or kerosene cans, singers frequently touched on contemporary political issues and social commentary. In contrast, the other most widespread genre, highlife, as its name implies, was more associated with the musical tastes of the upper classes and social elite. Performed at important events such as weddings, funerals, and holidays, highlife ensembles combined European band instruments and harmonic structures with distinctly African practices such as praise singing. Highlife's appeal was broadened by its origins in Ghana, the first African nation to gain independence (1957). Under the leadership of the charismatic prime minister Kwame Nkrumah, Ghana's political and cultural influence was strong throughout the region during the postcolonial period.

Nigeria, with 150 million people, the most populous country in sub-Saharan Africa, became independent in 1960. As in most of the continent, its borders were drawn during the 1885 Berlin Conference with little regard to different ethnic, religious, or linguistic groups, and these internal divisions were exploited by the European powers to maintain control. Nigeria includes over 250 ethnic groups, with the four largest the predominantly Muslim Hausa and 
Fulani in the north (29\%), the Yoruba in the southwest (21\%), and the Igbo in the southeast $(18 \%)$. The country was wracked by a brutal civil war from 1967 to 1970 when the Igbo attempted to form the independent republic of Biafra. After the defeat of the rebels, though governed by a series of military dictatorships, the nation entered a period of optimism fueled by enormous reserves of oil and a desire to become the political and cultural leader of the continent.

Nigeria's largest city, Lagos, while dominated by the Yoruba, is in many ways a postmodern collage of different ethnicities, nationalities, and cultures. The city's origins lie in the illicit slave trade. Built on a sandy island, its many creeks afforded hiding places for slave traders after the French (1791) and British (1807) outlawed the slave trade. Lagos became an important incubator for urban popular musics as the Kru mariners, as well as Ghanaians, Cameroonians, and others brought palm wine and highlife, which blended with Yoruba traditions, especially jújù.

As in highlife, jújù groups typically play for important social functions, often hired by the social and economic elite. Here they are expected to perform the traditional role of offering praises to their hosts both vocally and articulated by the sonically prominent talking drum or dundun. The social status of musicians as beggars is reinforced by the practice of "spraying" in which the hosts and their guests reward the musicians by pressing money to their foreheads. In the 1930s, as the "rhumba" craze (actually Cuban son montuno) ${ }^{1}$ swept much of the United States and Europe, highlife, palmwine, and jújù began to assimilate Caribbean rhythms, percussion instruments, and harmonic and formal structures. Calypso and other genres from English-speaking islands also became part of the mix. Latin and Caribbean influence in West Africa came not only through the African colonies' and Caribbean colonies' common tether to the European powers (particularly London), but through the important communities of repatriated former slaves and their descendants.

Lagos's importance as a center for music grew as Decca, EMI, and other record companies established recording studios in the city as they expanded their operations in Africa (Veal, 2000, 79). In the years after World War II the modern sound of jújù featuring electric instruments, especially guitars, was popularized by such artists as Tunde Nightengale, I. K. Dairo, Ebenzer Obey, and King Sunny Adé. The 1960s brought an influx of American soul music such as Otis Redding, Wilson Pickett, James Brown, and others. The postcolonial market was ripe for a new broadly popular music, one that appealed to different ethnicities and social classes, that internally was emblematic of Africaness but presented a modern face to the world. As an ambitious young musician, Fela Anikulapo (Ransome) Kuti was determined to create a genre to satisfy this demand. But his route to this innovation first led him to two important international black Atlantic destinations: London and the United States. 


\section{London (1958-63)}

Fela Kuti was born on October 15, 1938, in Abeokuta, a city about sixty miles north of Lagos on the Ogun River. ${ }^{2}$ His father, Reverend Israel Oldotun Ransome-Kuti, was a Protestant minister and school principal, and his mother was a feminist active in the anticolonial movement. Studying abroad was considered essential for career advancement in postcolonial Africa, and as a member of a solidly middle-class family, Fela was expected to follow suit. Unlike his siblings, who also went to London but chose the more respected route of medicine, Fela made the unconventional choice to study music at Trinity College. While his formal study in music included classical theory and composition as well as trumpet performance, Fela was more interested in jazz than in classical music. As some of his earliest recordings dating from this period confirm, his London years were devoted to mastering jazz improvisation and composing jazz tunes. Fela paid his dues by sitting in at jazz clubs such as Ronnie Scott's and hanging out with other jazz musicians, essential elements of a jazz education. As his chops developed, he was attracted to modal jazz, a style of modern jazz popularized by Miles Davis in his seminal album Kind of Blue (1959). While in London, Fela also continued to explore Caribbean traditions, most notably calypso jazz in the mold of Sonny Rollins's "St. Thomas" (released on Rollins's 1956 album Saxophone Colossus). Two of Fela's recordings from this period exhibit credible boppish improvisations on trumpet: "Great Kids," an original calypso with guitarist Medonal Amaechi, and "Amaechi's Blues," a hard bop modal tune that combines the soulful elements of Art Blakey's "Moanin" with the cooler stylings of Miles's "So What."

Upon his return to Lagos, Fela continued to compose and record out-andout highlife songs with his group Koola Lobitos ${ }^{3}$ as well as hybrids incorporating elements of rock, blues, and other popular genres along with jazz as he struggled to make a name for himself in the burgeoning West African popular music scene. The Lobitos' attempts at fusing jazz and highlife were not appealing to the tastes of the dance-oriented public. According to Fela, his own mother counseled: "Start playing music your people understand, not jazz" (Moore, 2009 [1982], 73). At this same time, soul music was gaining popularity as bands performed "copyright" songs (covers) of many American artists. The Sierra Leone singer Geraldo Pino (who, in an indication of the popularity of Caribbean music, had earlier Latinized his name from Gerald Pine), played note-for-note covers of James Brown. Also copying the Godfather of Soul's dance moves and playing on the latest sound equipment, Pino dazzled West African audiences before Brown's first triumphant trip to Africa in 1970.

During this important formative period Fela began important collaborations with other Nigerian musicians including Isaac Olasugba (saxophone), Tunde Williams (trumpet), and especially Tony Allen (drums). He also acquired his lifelong taste for "Indian hemp" (marijuana). By the late 1960s, after spending time performing in the Ghanaian capital of Accra, Fela had concluded that 
a U.S. tour could help propel him and the Lobitos to the forefront of the West African popular music scene. ${ }^{4}$

\section{United States (1969-70)}

Fela and the Lobitos arrived at Kennedy Airport in June 1969 to an enthusiastic greeting from members of New York City's Nigerian community. The bandleader soon discovered, however, that his sponsors, African Tours Limited, had mostly abandoned them. The group traveled on their own to gigs in Washington, D.C., Chicago, and San Francisco, before finally ending up stranded in Los Angeles (Veal, 2000, 67). What followed was a series of disasters as they encountered problems with immigration authorities, difficulties with a musicians union, and even their negligent promoter blocking any attempts to book work on their own. It was the height of the Biafran conflict and, right before an important gig, their bassist, Felix Jones, who was Igbo, went into hiding out of fears of persecution from the U.S. authorities who were backing the federal government. Fela, who was determined not to return home empty handed, eventually focused his efforts on recording their most recent material.

In Los Angeles Fela began a relationship with a woman who would radically change his thinking. A singer and former Black Panther, Sandra Smith (Isadore) introduced him to the ideas and writings of Martin Luther King, Jr., Kwame Ture (Stokely Carmichael), Nikki Giovanni, The Last Poets, Jesse Jackson, Nina Simone, Eldridge Cleaver, Angela Davis, and, above all, Malcolm X (Moore, 2009 [1982], 95). At the time, because Fela mostly listened and rarely commented, Smith assumed that Fela was already politically aware, that he had been exposed to Black Nationalism, Pan-Africanism, and other ideas. Like many African Americans, Smith was eager to learn about African culture, and, after all, Fela was African. She discovered only much later, during her second trip to Africa in 1976, when she recorded the Upside Down album with Fela, that, indeed, everything had been upside down. Fela had been learning at least as much from her as she had been from him.

In addition to letting Fela stay at her house, Smith helped secure a steady gig for the band in Hollywood at Citadel D'Haiti and sang with the group, which now had been renamed Nigeria $70 .{ }^{5}$ The Citadel, which had been "the emptiest club on the whole Sunset Boulevard," was starting to pull in a crowd, and the band's performance schedule was expanded to five nights a week. One night Fela decided to premier a new song. According to Fela, the crowd's reaction to his new work was dramatic: "The whole club started jumping and everybody started dancing. I knew I'd found the thing, man. To me, it was the first African tune I'd written till then" (Moore, 2009 [1982], 86-88).

Although Fela had coined the term Afrobeat as early as 1968 while he was still in Nigeria, it was in Los Angeles that he hit upon the innovations that would come to characterize his new style: 
One day I sat down at the piano in Sandra's house. I said to Sandra: 'Do you know what? I've just been fooling around. I haven't been playing AFRICAN music. So now I want to try to write African music ... for the first time. I want to try.' ... Then I started to write and write. In my mind I put a bass here ... a piano there. ... I said to myself, 'How do Africans sing songs? They sing with chants. Now let me chant into this song: la-la-la-laaa. . . .' Looking for the right beat I remembered this very old guy I'd met in London-Ambrose Campbell. He used to play African music with a special beat. I used that beat to write my tune, man.' (Moore, 2009 [1982], 85)

Oladipupo Adekoya “Ambrose" Campbell (1919-2006) had also served as an earlier musical role model for jújù musicians active in the style known as Toy Motion in the late 1950s (Waterman, 1990, 96-97). In their rejection of praise songs and embracing of marijuana ("toy" was a euphemism for marijuana) the Toy Motion substyle was a clear antecedent for Fela's Afrobeat subculture. ${ }^{6}$

Fela named his new song "My Lady's Frustration" in honor of his relationship with Sandra, and in acknowledgment of the band's continued lack of recognition despite her dedication to their cause. Fela's time in the United States had not been easy. But the experience had brought about profound changes in his worldview and his music:

Ten months in America. Ten terrible months. ... America had been both bitter and sweet. . . Who was I? It was in America I saw I was making a mistake. I didn't know myself. I realized that neither me nor my music was going on the right direction. I came home with the intent to change the whole system. ... I didn't know they were going to give me such opposition because of my new Africanism. How could I have known? As soon as I got back home I started to preach. I decided to change my music. And my music did start changing according to how I experienced the life and culture of my people" (Moore, 2009 [1982], 89).

Missing in Fela's account, though understandable in his effort to emphasize the Africanness of his new style, is acknowledgment of American soul artists, in particular, James Brown, whose music and career were reaching a creative peak. The next section compares elements of James Brown's and Fela's music in order to understand how funk informed Fela's new Afrobeat style.

\section{Funky Drummer}

While Campbell may have inspired Fela's new beat, the drummer Tony Allen (b. 1940) supplied the actual grooves that drove much of Fela's music. 
Performing on more than thirty albums, Allen helped define the band's sound until his departure in 1979 after the breakup of Africa $70 .^{7}$ Fela, never known for effusive praise of his sidemen, reportedly acknowledged that, "without Tony Allen, there would be no Afrobeat."

Their collaboration began in Koola Lobitos in 1964 after Fela returned from London. Allen had been playing with various highlife groups including Dr. Victor Olaiya's Cool Cats, Agu Norris and the Heatwaves, the Nigerian Messengers, and the Melody Makers. By the time Fela heard him, Allen had developed a unique blend of Yoruba and highlife rhythms and jazz. He was one of the first West African drummers to incorporate the hi-hat (a pair of cymbals on a stand that are opened and closed by a foot pedal): "I read an article by Max Roach about the hi-hat. None of the African drummers used a hi-hat so I studied it and that became part of my sound." Impressed with Allen's musicianship, Fela asked: "How come you are the only guy in Nigeria who plays like this - jazz and highlife?" (Williamson, 2008). Fela was still known in Nigeria as a jazz musician (in fact he won a 1966 popularity poll as the leading jazz musician in Nigeria) (Waterman, 1990, 241), but Allen and Fela's collaboration was to help change that perception.

Allen was one of the few members of the band Fela trusted to make up his own parts. At the time the drummer joined the band, "Fela used to compose at the keyboard and transpose the lines to tenor guitar. He would write down all the parts which the musicians had to copy, including the drum patterns." After the U.S. trip, Allen notes, "we got onto the same wavelength and Fela would ask what type of rhythm I wanted to play. It was complicated at first, too much, but I advised him to keep it simple. It is hard work playing African music. It sounds simple but it is not, especially drumming." (Ewens, 1991, 102)

James Brown's visit to Lagos in 1970 is often cited as a milestone in African popular music, but Allen disputes the chronology:

"We'd already heard him and assimilated what he did by then," he insists. "None of the Nigerian musicians got to see James Brown when he came to Africa because he played only for the rich people in a five-star hotel. What really happened was that his musicians came to our club to see us every night after their show" (Williamson, 2008).

In fact, as will be seen in my analysis below, while Allen's playing may have been influenced by Brown's drummers, Allen contributed distinctive funky grooves of his own invention.

I have discussed more fully in another article a fundamental rhythmic shift that occurred in American popular music in the early 1960s as early rock 'n roll and rhythm and blues gave way to rock and soul (Stewart. 2000). This transformation involved a change from swing and shuffle rhythms, basically triplet subdivision of the beat, to "straight" or even eighth notes (duple subdivision). 
While this change could be regarded as a simplification of the meter, it paved the way to greater rhythmic complexity as the beat was further subdivided into the sixteenth-note or quadruple subdivision that characterized funk. ${ }^{9}$ The sources for this transformation were multiple: New Orleans marches, gospel, Latin music, downhome blues, and more. In the words of Clayton Filyau, a drummer who helped bring this complex funky style of playing based on sixteenth-note subdivision to the James Brown band: "Everything back then was shuffles, but I didn't like those shuffles. I like syncopation. I like to play rhythms against rhythms" (Payne, 1996, 22).

Brown exercised a high level of artistic control (unusual for black artists at that time) that enabled him to foreground this more active, aggressive style of drumming. On the road he frequently carried five or six drummers, and even though only one played at a time, he seemed to relish the visual effect of the many drum sets on stage. His large bullpen of drummers also enabled him to make frequent changes during his four-hour shows if he wanted fresh energy or a different feel. Many musicians and listeners perceived "African" qualities in this heightened emphasis on percussion (see, for example, Hirshey, 1984; Guralnick, 1986, 239-43; Brackett, 1992), although Brown himself denied any direct African influence (Brown, 1997 [1986], 221). At various times, besides Filyau, Brown's roster of drummers included masters such as Melvin Parker, William "Beau Dollar" Bowman, Nate Jones, and, especially, John "Jabo" Starks and Clyde Stubblefield. Most of their grooves consist of one- or twomeasure drum patterns or cells that are repeated for entire verses or bridge sections. The following table gives the distribution of one- and two-measure funk grooves in many of Brown's best known songs.

\begin{tabular}{|l|l|l|}
\hline Year & One-Measure Funk Grooves & Drummer \\
\hline 1968 & Lickin' Stick & John “Jabo” Starks \\
\hline 1968 & Say It Loud (I'm Black and I'm Proud) & Clyde Stubblefield \\
\hline 1968 & Give It Up (bridge) & Nate Jones \\
\hline 1968 & Soul Pride Parts 1 and 2 & Clyde Stubblefield \\
\hline 1969 & Funky Drummer & Clyde Stubblefield \\
\hline 1970 & Get Up (I Feel like Being a Sex Machine) & John “Jabo” Starks \\
\hline 1970 & Got to Getcha & Melvin Parker \\
\hline 1970 & Super Bad & John “Jabo” Starks \\
\hline 1970 & Talkin' Loud \& Sayin' Nothing & John “Jabo” Starks \\
\hline 1971 & Make It Funky & John “Jabo” Starks \\
\hline 1971 & Soul Power & John “Jabo” Starks \\
\hline 1972 & I Know You Got Soul & John “Jabo” Starks \\
\hline 1972 & Get on the Good Foot & John “Jabo” Starks \\
\hline
\end{tabular}




\begin{tabular}{|l|l|l|}
\hline Year & Two-Measure Funk Grooves & Drummer \\
\hline 1967 & Cold Sweat & Clyde Stubblefield \\
\hline 1967 & I Can't Stand Myself & William “Beau Dollar” Bowman \\
\hline 1968 & I Got the Feelin' & Clyde Stubblefield \\
\hline 1968 & Give It Up (verse) & Nate Jones \\
\hline 1969 & Mother Popcorn & Clyde Stubblefield \\
\hline 1970 & Give It Up (bridge) & Clyde Stubblefield \\
\hline 1970 & Super Bad & John "Jabo" Starks \\
\hline
\end{tabular}

All of these grooves have in common an emphasis on the downbeat of the first measure counterbalanced with a flurry of syncopated activity in the latter part of the pattern. The tension created by this syncopation leads back to the stability of the first beat or "the one." In his memoirs Brown explained how "key[ing] in on the dynamic parts of the one" allows a player "to do all his stuff in the right places - after the one" (Brown, 1986, 218-19). The two-measure grooves are even more complex, taking two measures before resetting on the first beat; that is, the second measure of the pattern does not accent the first beat.

While many of Brown's grooves consisted of two-measure as well as onemeasure patterns, most of the grooves supplied by Allen are built from singlemeasure patterns. One way of comparing rhythmic patterns is by using TUBs (Time Unit Boxes notation). In addition to clearly aligning the beats for ease of comparison, this method does not require an ability to read conventional Western musical notation. Example 1 illustrates how a drum pattern incorporating the different instruments of the drum set can be depicted in TUBs notation. Each of the three instruments (hi-hat, snare, and bass drum) is given one row in the accompanying TUBs notation. As can be seen, this drum pattern subdivides the four beats into eight equal parts (which could be counted as "one-and-twoand-three-and-four-and"), or eighth-note subdivision.

\section{Example 1}

A Basic Rock/Soul Drum Pattern: "In the Midnight Hour” by Wilson Pickett (1965), Al Jackson, drums

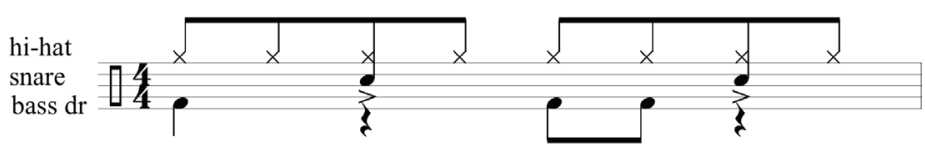




\begin{tabular}{|l|l|l|l|l|l|l|l|l|l|l|l|l|l|l|l|l|}
\hline Count & 1 & & + & & 2 & & + & & 3 & & + & & 4 & & + & \\
\hline Hi-hat & $\mathrm{X}$ & & $\mathrm{X}$ & & $\mathrm{X}$ & & $\mathrm{X}$ & & $\mathrm{X}$ & & $\mathrm{X}$ & & $\mathrm{X}$ & & $\mathrm{X}$ & \\
\hline Snare & & & & & $\mathrm{X}$ & & & & & & & & $\mathrm{X}$ & & & \\
\hline Bass drum & $\mathrm{X}$ & & & & & & & & $\mathrm{X}$ & & $\mathrm{X}$ & & & & & \\
\hline
\end{tabular}

The next example gives the same pattern with only the bass (B) and snare drums (X), leaving out the hi-hat. Notice the snare backbeat on two and four (a standard feature of much swing, rhythm and blues, and soul) and the bass drum on the first and third beats. A third bass drum attack on the "and" of three provides a bit of syncopation and forward momentum.

\section{Example 2}

\begin{tabular}{|l|l|l|l|l|l|l|l|l|l|l|l|l|l|l|l|l|}
\hline Count & 1 & & + & & 2 & & + & & 3 & & + & & 4 & & + & \\
\hline BD \& SN & B & & & & $\mathrm{X}$ & & & & $\mathrm{B}$ & & $\mathrm{B}$ & & $\mathrm{X}$ & & & \\
\hline
\end{tabular}

$\mathrm{B}=$ bass drum

$\mathrm{X}=$ snare

Using TUBs notation, Example 3 compares various one-measure grooves used in Brown's music. I have simplified the grooves by leaving out cymbal and hi-hat parts and included only the main accents on bass drum (B) and snare (X). While hi-hat and ride cymbal parts are obviously significant to the overall groove (especially in regard to maintaining the beat subdivision) the drum parts figure more importantly in establishing the pattern of emphasized downbeats and syncopation. Several common features are easily seen. First, in the bass drum, every example except one ("Funky Drummer Part 1") has a bass drum downbeat on beat one and an offbeat on the "and" of three. Second, all (except "Superbad"), like most soul music grooves, have a strong snare backbeat on two and four. Finally, most of the syncopated sixteenth-note figures are reserved for the latter part of the pattern (beginning on the last sixteenth note before beat three). Notice that in most of these grooves the bass drum part is derived from the standard soul groove in Example 1, except that the downbeat on beat three has been left out. This heightens the rhythmic tension created by the snare drum's syncopation during the second half of the pattern. 


\section{Example 3}

James Brown, One-Measure Funk Grooves

\begin{tabular}{|l|l|l|l|l|l|l|l|l|l|l|l|l|l|l|l|l|}
\hline Count & 1 & & + & & 2 & & + & & 3 & & + & & 4 & & + & \\
\hline Licking Stick & B & & & & X & & & X & & X & B & & X & & B & X \\
\hline Say It Loud & B & & & & X & & & X & & X & B & X & X & X & B & X \\
\hline Funky Drummer 1 & & & B & & X & B & & X & & X & & & X & B & & X \\
\hline Funky Drummer 2 & B & & B & & X & & X & X & & X & B & X & X & B & X & X \\
\hline Got to Getcha & B & & & B & X & & & B & B & & B & & X & B & & B \\
\hline Give It Up & B & & B & & X & & & X & B & X & B & X & X & B & & B \\
\hline Sex Machine & B & & & & X & & X & X & & X & B & & X & & B & \\
\hline Super Bad & B & & & & & & X & & & X & B & & X & & B & \\
\hline Make It Funky & B & & & & X & & & X & B & X & B & & X & & B & X \\
\hline Soul Power & B & X & B & & X & & & X & & X & B & & X & & & X \\
\hline $\begin{array}{l}\text { I Know Got You } \\
\text { Got Soul }\end{array}$ & B & X & & & X & & X & X & & X & B & & X & & X & X \\
\hline Good Foot & & & & & & & & & & & & & & & & \\
\hline
\end{tabular}

Example 4 provides examples of Tony Allen's grooves for selected Fela tunes. Several of these, in particular, "Expensive Shit," "Equalisation of Trouser and Pant," "Alagbon Close," "Kalakuta," and "Yellow Fever," have been cited as paradigms of Fela's "seamless blend of highlife and James Brown-styled funk" (Veal, 2000, 98, 144).

\section{Example 4}

Some Fela Funk Grooves, Tony Allen, drums

\begin{tabular}{|l|l|l|l|l|l|l|l|l|l|l|l|l|l|l|l|l|}
\hline Count & 1 & & + & & 2 & & + & & 3 & & + & & 4 & & + & \\
\hline $\begin{array}{l}\text { My Lady's } \\
\text { Frustration }\end{array}$ & B & B & & X & B & B & & X & B & & B & & & B & & X \\
\hline No Agreement & B & B & X & & B & B & X & & B & B & & X & & & X & \\
\hline $\begin{array}{l}\text { Equalisation of } \\
\text { Trouser \& Pant }\end{array}$ & B & B & X & X & & X & & & B & B & & X & & & X & X \\
\hline Alagbon Close & X & X & & & X & & B & & X & X & & B & & & B & \\
\hline Kalakuta & B & B & & B & & B & X & X & & & & & X & & X & \\
\hline Yellow Fever & B & B & & X & & & & & B & X & B & & X & & X & \\
\hline Expensive Shit & B & X & & B & & & B & & X & X & & & X & X & B & \\
\hline Shenshema & B & B & & X & & & X & & B & B & & & X & & X & \\
\hline $\begin{array}{l}\text { Sorrow, Tears \& } \\
\text { Blood }\end{array}$ & B & B & & & X & & X & & B & X & B & X & & & X & \\
\hline
\end{tabular}


As can be seen in Example 4, the patterns used by Allen are conceptually similar to those played by Brown's drummers. Both place a strong accent on beat one and use sixteenth-note subdivision. All are satisfying by balancing regular patterns of accents on selected downbeats with those on offbeats, especially syncopated sixteenth notes. A pattern that only contained offbeats would not be effective, especially for dancers, because it would not clearly establish a basic underlying beat. Both Brown's and Fela's grooves tend to place a strong accent on the "and" of four, which sets up the return to beat one. ${ }^{10}$ Still, Brown's drummers' and Allen's patterns differ in dramatic ways: the absence of the snare backbeat on two and four, the more balanced syncopation (occurring in Allen's grooves in the first half of the measure as well as the second half), and the more frequent sounding of the bass drum. This usage of the bass drum seems reflective of traditional West African practices in which the largest drum is often the lead drum. ${ }^{11}$

At the same time, Allen contributed other distinctive grooves that maintained, in tandem with the other percussionists (particularly the band's conga players), the Caribbean rhythmic foundations heard in so much highlife. Some of these grooves, particularly those in more moderate tempos, still foregrounded one-measure patterns in the congas (called tumbao by North American musicians) and other Latinized African American grooves such as boogaloo. However, clave stick patterns, the most explicit Afro-Cuban pattern heard extensively in jújù and highlife, were notably absent. Instead of the asymmetrical five-stroke pattern of clave, a signature element of many of Fela's Afrobeat grooves was a symmetrical sticks pattern of two quick sixteenth-note strokes on the off beats (or "ands") as seen in Example 4.

\section{Example 5}

\begin{tabular}{|l|l|l|l|l|l|l|l|l|l|l|l|l|l|l|l|l|}
\hline Count & 1 & & + & & 2 & & + & & 3 & & + & & 4 & & + & \\
\hline Sticks & & & $\mathrm{X}$ & $\mathrm{X}$ & & & $\mathrm{X}$ & $\mathrm{X}$ & & & $\mathrm{X}$ & $\mathrm{X}$ & & & $\mathrm{X}$ & $\mathrm{X}$ \\
\hline
\end{tabular}

\section{Other Elements}

While the new drum and percussion grooves provided the rhythmic foundation, other important elements also contributed to Fela's new Afrobeat style. Some of these elements bore even more traces of Brown's funk style.

As mentioned earlier, the guitar-acoustic, electric, and even the pedalsteel (more associated with Hawaiian and country music in the United States) has been central to much West African popular music. In palmwine, highlife, and jújù, the guitar often plays variations on the main themes of the piece between vocal sections. This instrument also figured importantly in Brown's emergent funk style as he began to use two guitarists in very distinct roles. Instead of sounding sustained chords, the rhythm guitarist mutes the strings on the fretboard with one hand while his other hand slides the pick across two or three 
strings, yielding a percussive, scraping sound known as "chicken scratch." Occasional chords are allowed to ring out adding to the dense syncopated texture. Meanwhile, the other guitarist, sometimes referred to as the tenor, plays single-note melodic/rhythmic ostinatos (repeated figurations) that interlock with the rhythm guitar (and the other rhythm section instruments). As Brown later explained: "I was hearing everything, even the guitars, like they were drums" (Brown, 1997 [1986], 158).

While musical textures featuring interlocking parts are central to much African music, in Fela's funk grooves, the two distinctive guitar parts - rhythm and single-note or tenor-are strongly reminiscent of Brown's technique. Fela's rhythm guitar parts, however, are less often scratched to the extent of Brown's, that is, played with the strings fully muted. Example 5 shows how the different rhythm section parts fit together in Fela's "Alagbon Close."

\section{Example 6}

"Alagbon Close"

\begin{tabular}{|l|l|l|l|l|l|l|l|l|l|l|l|l|l|l|l|l|}
\hline Count & 1 & & + & & 2 & & + & & 3 & & + & & 4 & & + & \\
\hline Tenor guitar & X & & X & & X & X & & & X & X & & X & & X & X & \\
\hline Rhythm guitar & & X & & X & X & & X & & X & & X & & X & & X & \\
\hline Bass & X & & & & & & X & & & X & & X & & & X & \\
\hline Drums & X & X & & & X & & B & & X & X & & B & & & B & \\
\hline Sticks & X & X & & & X & X & & & X & X & & & X & X & & \\
\hline
\end{tabular}

As Brown developed his "brand new bag" he also began to use other melodic instruments besides the guitars more percussively. In his words: "I had discovered that my strength was not in the horns, it was in the rhythm. . . Later on they said it was the beginning of funk, I just thought of it as where my music was going" (Brown, 1997 [1986], 158). The horns' sparse riffs provided punctuation to the dense grooves and vocal statements. While at times Fela used them similarly, in Afrobeat the horns' primary function, besides taking extended solos, was to state important melodic themes of the composition. As the guitars became more rhythmic in Fela's music, the horns assumed some of the melodic responsibility formerly held by the guitars in West African popular traditions.

Both Brown and Fela gave their horn players ample solo space, though in Brown's band this responsibility rested primarily with saxophonists, such as Maceo Parker. In Africa 70 Fela featured Olasugba and Williams, besides himself on tenor and soprano saxophone (he had given up trumpet because of the strain on his lips). Neither bandleader seemed to favor guitar solos, perhaps reflecting their greater influence from modern jazz instead of rock.

One element of Fela's Afrobeat that seems to have little indebtedness to Brown is his vocal style. As Fela mentioned in discussing his creation of "My 


\section{Alexander Stewart}

Lady's Frustration," chanting was a central element in his Afrobeat innovation. Rather than mimic Brown's trademark screams and growls, much of which derived from gospel and the sanctified church, Fela's rich baritone drew upon Yoruba chant and vocables (nonlexical syllables). In some songs (for example, "My Lady's Frustration"), the entire vocal consisted of such wordless texts.

Unlike traditional highlife and jújù performances, in which the duties of praise singing demanded certain flexibility, Fela's compositions tended to be relatively fixed. Structurally, a Fela song might begin with a basic groove, go into lengthy horn solos, followed by chanting, a call and response section between him and the chorus, and more solos before drawing to a close some twenty or thirty minutes later. The endurance of some of the band members was phenomenal to say the least, perhaps most for those playing simple repetitive parts such as the sticks (in Example 5) and the guitar patterns. Like Brown, Fela assumed almost dictatorial control of his band and enforced strict discipline. ${ }^{12}$ While disputes over pay were common, Allen and the horn soloists enjoyed a bit more musical freedom than the other members. Allen accentuated important hits with the horn players and set up transitions and important structural points with fills (brief rolls and other bursts of improvised percussive activity). The use of static harmonies (a single chord rather than a progression) was an essential part of both Brown and Fela's compositional styles, though Brown tended more toward the bluesier sound of dominant seventh chords while Fela preferred the cool minor-seventh or Dorian sound of modal jazz. In many of Brown's songs, an important structural element was modulation to a new key during a bridge section. A climactic point in the performance came when Brown implored the band or the audience for permission to "take it to the bridge." In Fela's mature Afrobeat style such tonal shifts were rare. The entire song, sometimes lasting thirty minutes or more, maintained a single tonality.

Both Brown and Fela identified with the street as reflected in their language. As one of Brown's biographers has noted, from the mid-1960s he made "a clear switch from the language of love common to southern soul music to hipper streetsier phrases that drive and give energy to the cadences of urban street talk" (Brown, 2008 [1996], 92). Fela's decision to sing in Pidgin English rather than his educated English or Yoruba reflected a similar strategy to use the rhythms and slang of the streets of Lagos while remaining intelligible in much of Africa and beyond. More than Brown, he explicitly rejected love songs as a product of bourgeois capitalist society and un-African.

On stage, unlike Geraldo Pino, Fela did not simply mimic the signature dance moves of Brown, "the hardest working man in show business." Abandoning his cool jazz demeanor of his earlier days, Fela "had developed into a masterful dancer, his style a hybrid mixture of traditional steps and rapid footwork recalling Brown —all projected with a sinuous sensuality" (Veal, 2000, 100). Besides his large stage retinue, visitors to his club, the Shrine, were awed (and sometimes shocked) by the sight of female go-go dancers in booths beside the stage. 


\section{Africa 70 to Egypt 80}

As musical styles in the United States changed in the mid-1970s, Brown's popularity suffered a rapid decline. Disco songs, while retaining some of the funkier aspects of the horn parts and rhythm section parts, featured much simpler "four-on-the-floor" drum parts in which all four downbeats were sounded in the bass drum and syncopation was minimal. Raw funk was smoothed over with slick arrangements and orchestrations as well as more complicated chord progressions. Brown's music was eclipsed by the emergence of these new styles until appearances in such 1980s films as Blues Brothers and Rocky IV helped revive his career.

The mid-1970s were much kinder to Fela as he entered his most prosperous period and produced his "most focused, cohesive and incisive work" (Veal, 2000, 148). Bookended by his brief imprisonment in Alagbon Close on marijuana charges in 1974 (documented on his Expensive Shit album) and the devastating raid in February 1977, Fela's career peaked not only in terms of financial success and popularity, but also in the growth of his political and cultural influence. His compound, now renamed the Kalakuta Republic (Swahili for "rascal") for the cellblock where he had been confined, was fortified and expanded with the construction of his own recording studio. Determined to shed remaining vestiges of colonial mentality, in 1975 Fela dropped Ransome from his name and adopted the militant moniker Anikulapo ("he who carries death in his pouch"). To show her support, his mother also changed her name. His experiences became raw material for his art as his songs chronicled these events evidenced in the titles of some of his most popular works: "Expensive Shit," "Alagbon Close," "Colonial Mentality," "Kalakuta Republic," and so forth.

A series of clashes with successive military dictatorships culminated in Fela's boycott of the huge FESTAC celebration hosted by Nigeria in 1977. Intended by the government as a showcase for Nigerian cultural hegemony over Africa, the regime was profoundly embarrassed by the country's biggest star refusing to participate. A brutal raid on Fela's compound resulted in its complete destruction (including the studio and valuable master tapes), severe injuries to many of his followers, a lengthy hospitalization and imprisonment for Fela, and the eventual death of his mother, who had been living at the compound. While his stature as an international star was growing, Fela was banned from working in Nigeria, and he was financially devastated. Calling himself the Black President, he became increasingly preoccupied with his political ambitions, which led to ever greater neglect of his musicians, culminating in Africa 70 breaking up as Allen and other core members departed after a tour to Berlin in 1979. Fela's new band, called Egypt 80, continued to perform Afrobeat music even as newer styles of rap and hip hop started to become popular in Nigeria. Fela died as a result of complications from AIDS in 1997. 


\section{Conclusions}

Fela's invention of Afrobeat was a process of assimilation and synthesis that took at least a decade and that to some extent mirrored other trends occurring in West African popular music as American soul music gained popularity. His experiments resulted in a new musical art form in which at least three musical strands, though thoroughly integrated, are not homogenized or blended to the point they disappear. Highlife and other African traditions (along with their prior absorption of Latin and Caribbean music), jazz, and funk remain distinctly audible. While some of these musical strands were also identifiable in other contemporary West African popular genres, one ingredient that distinguished Fela from most of his competitors in his Afrobeat mix was his enduring rootedness in jazz.

Significantly, Fela had already decided on a name for his new genre, before he had even settled on its musical recipe. Waterman discusses the plethora of named musical genres in Yoruba popular music and their connection to hierarchical occupational and other social categories (Waterman, 1990, 15-17). The naming of a genre is, of course, also a marketing strategy and endows its creator with individual authority. The "beat" in Afrobeat signified the importance of groove and at the same time distinguished the genre from a generic and more clearly American-related Afrofunk.

Yet, despite attempts to downplay the influence of American soul and funk, Fela's Afrobeat owed a considerable debt to the music of James Brown. As we have seen, this borrowing consisted of concepts, styles, and practices, all of which were adapted to the sensibilities of Fela and his musicians. In a time of rising black consciousness and activism, both Brown's and Fela's music reflected profound differences in perspective. As illustrated dramatically in the experiences of Sandra Isadore, even while many African Americans were looking to make a connection to Africa, to the citizens of the newly minted nations of Africa, the idea of "Africa" barely existed as more than an abstract concept.

Shifting attitudes toward nationalism and "blackism," using Fela's term, played out differently in each performer's music and career. Reflecting on his regal treatment during a 1975 visit to Gabon, Brown proclaimed: "This [was] not just an ordinary engagement. Every century has a messiah. People look on me as a messiah in Africa because they see I can bring all black people together" (George and Leeds, 2008, 123). Ten years later, after a steep decline in popularity, Brown released his first hit in as many years, "Living in America." Concocted by Sylvester Stallone and pop songwriter Dan Hartmann to help promote Rocky $I V$, the watered-down funk song was an unabashedly patriotic anthem in the time of Reagan-style revivalism. With Brown's newly found crossover appeal, as Smith notes in his biography, The One, "It was an astounding transformation for a figure that many in the country had never before viewed as American" (Smith, 2012, 338). To some extent, Fela moved in an opposite trajectory. Before his trip to the United States, Fela had witnessed 
the terrible destruction of the Nigerian civil war and had supported the federal government in its efforts to hold the young nation together. The names of Fela's groups reflected his ideological evolution from nationalism to Pan-Africanism to blackism as Nigeria 70 gave way to Africa 70 , and, ultimately, to Egypt 80 .

Both Brown and Fela readily embraced the responsibility that came with their stardom and leadership roles. Whatever disadvantages Fela felt due to the underdeveloped status of his nation, compared to Brown, the inventor of Afrobeat actually enjoyed distinct advantages related to social class. With his middle-class upbringing, Fela early on was exposed to a more cosmopolitan outlook and received a first-class education including musical training in classical music and jazz. Brown, as is well known, dropped out of school after seventh grade, shined shoes, picked cotton, danced for pennies in the streets of Augusta, Georgia, and, convicted of armed robbery, spent time in juvenile detention where he fell in with Bobby Byrd's gospel group. Music was Brown's salvation, while for Fela, at least in the beginning, it was a career path.

Fela and Brown's music shared a message of empowerment and self-sufficiency, but within very different contexts. After his trip to the United States, Fela remained acutely aware of the disadvantages of underdevelopment. Brown was not seeking to overthrow the political and economic structure as much as to find opportunity within it. "Say It Loud, I'm Black and I'm Proud" was informed by bootstrap rhetoric like "Don't Be a Dropout" and "I Don't Want Nobody to Give Me Nothing (Open Up the Door I'll Get It Myself)." Fela not only had to deal with the remnants of a racist colonial system, but with the corruption and disorganization of a political order constantly in a state of near collapse. Even with these obstacles, Nigeria and the United States share an optimism deriving from notions of upward mobility. In Nigeria, however, rather than idealized American notions of meritocracy, social capital based on customary relationships of ethnicity, community, and family is seen as determinative of success. Anyone can make it by knowing the right people. Sudden prosperity and corruption fed by the oil boom intensified and distorted traditional reciprocal relationships. Fela's uncompromising stance, as epitomized by his refusal to sing praise songs and the absence of talking drums, indicated his rejection of certain African traditions even as he made his music more African. Near the end of his career, Fela's increasing obsession with running for political office led to accusations from band members that he was putting political ambitions ahead of the music.

Today, in North America and Europe, Afrobeat is enjoying a revival as numerous groups perform Fela covers and new compositions inspired by his grooves. ${ }^{13}$ In 2009 a show celebrating his music and life began a fifteen-month run on Broadway and a road production continues to tour including a short stint in Lagos. ${ }^{14}$ Meanwhile, the funk grooves that inflected Fela's music continue to circulate the black Atlantic in rap and hip hop. Much like soul and funk, it would take at least a decade for hip hop to become thoroughly fused with West African popular music traditions in a distinctly Nigerian or naija rap..$^{15}$ 


\section{Notes}

1. "Rumba" is an Afro-Cuban secular music and dance genre featuring percussion instruments and vocals. Cuban son, which eventually became the basis for much salsa, typically features string instruments (guitar, bass, tres, etc.), trumpets, and other instruments in addition to percussion. "Rhumba" (with an "h") was the label misapplied to son as it achieved commercial success outside Cuba in the 1930s with songs such as Don Azpiazú's "El Manisero" (The Peanut Vendor).

2. For more detail on Fela's life and career, see Michael Veal's definitive musical biography, Fela: The Life and Times of an African Musical Icon (Philadelphia: Temple University Press, 2000).

3. The name Lobitos, Spanish for "little wolves," reflected the continuing appeal of Latin music and culture.

4. Fela probably was also inspired by the success in the United States of another African musician, Hugh Masekela, whose song "Grazing in the Grass" had climbed to a number one position on the pop charts in the summer of 1968.

5. In his choice of names, perhaps Fela was influenced by the popularity of Sergio Mendes and Brazil '66.

6. Like Fela, Campbell came from a middle-class background, though his family was part of the Saro community of descendants of repatriated slaves. His career is a fascinating study in black Atlantic musical currents. In the 1930s he recorded with the popular palmwine group, the Jolly Orchestra, which besides other Saros included, Kru, Yoruba, and Ashanti musicians (Waterman, $1990,49)$. In the 1940s he arrived in England and by the 1950 s was performing with other black musicians from Trinidad and Barbados known as the West African Rhythm Boys. Campbell came to Los Angeles in 1972 and toured with Leon Russell. Eventually he ended up in Nashville after contributing to the Willie Nelson and Leon Russell collaboration and hit record "One for the Road." In 2004 he returned to the United Kingdom.

7. Besides emphasizing its "Africaness" by citing Campbell as the main influence for the beat in "My Lady's Frustration," Fela may have been reluctant to give Allen much credit in this interview, which was conducted soon after Allen's departure.

8. See Nigel Williamson, "Tony Allen: The Veteran Afrobeat Drummer Is Shaking His Sticks as Hard and as Brilliantly as Ever," The Independent, January 18, 2008, retrieved 2008. No citation is provided for this quote.

9. A measure containing four beats (as does most Western popular music) in which each beat is subdivided by two will have eight subdivisions, while a triplet subdivision yields twelve, and quadruple or sixteenth-note yields sixteen.

10. The accent on the "and" of four is an important marker of New Orleans second-line grooves. See Stewart, 2003.

11. Locke, 1987, 11. See also Chernoff's discussion of "master drums" in Ewe ensembles $(1979,43)$.

12. While Brown was fond of fines that were taken out of a sideman's pay, Fela seemed to prefer public humiliation, even stopping a performance or berating a player on stage.

13. For example, Antibalas and Akoya Afrobeat based in Brooklyn, the Chicago Afrobeat Project, and groups in Toronto, Vermont, and elsewhere.

14. The show, directed and choreographed by Bill T. Jones, reopened on Broadway for a repeat series of performances from July 12 to August 4, 2012.

15. The website "Nigerian Rap: The First Decade (1981-1991)" provides a fascinating look at this process: http://www.africanhiphop.com/africanhiphopradio/naija-nigerian-80s-rap-on-vinyl/, accessed July 22, 2012.

\section{Works Cited}

Brackett, David. “James Brown’s 'Superbad' and the Double-Voiced Utterance." Popular Music 11, no. 3 (1992): 309-24.

Brown, Geoff. The Life of James Brown. London: Omnibus Press, [1996,] 2008. Brown, James, with Bruce Tucker. James Brown: The Godfather of Soul. New York: Thunder's Mouth Press, [1986], 1997.

Chernoff, John Miller. African Rhythm and African Sensibility: Aesthetics and Social Action in African Musical Idioms. Chicago: University of Chicago Press, 1979. 
Darnton, John. "Nigeria's Dissident Superstar." New York Times Magazine (July 24, 1977): 10-12; 22-26.

Ewens, Graeme. Africa O-Ye: A Celebration of African Music. London: Guinness Publishing, 1991.

George, Nelson, and Alan Leeds, editors. The James Brown Reader: 50 Years of Writing about the Godfather of Soul. New York: Penguin, 2008.

Gilroy, Paul. The Black Atlantic: Modernity and Double Consciousness. Cambridge, MA: Harvard University Press, 1993.

Guralnick, Peter. Sweet Soul Music. New York: HarperCollins, 1986.

Hirshey, Gerri. Nowhere to Run. New York: Time Books, 1984.

Locke, David. Drum Gahu: The Rhythms of West African Drumming. Crown Point, IN: White Cliffs Media, 1987.

Moore, Carlos. Fela: This Bitch of a Life. Chicago: Lawrence Hill Books, [1982], 2009.

Payne, Jim. Give the Drummers Some: The Great Drummers of R\&B, Funk and Soul. Katonah, NY: Face the Music Productions, 1996.

Smith, R. J. The One: The Life and Music of James Brown. New York: Gotham Books, 2012.

Stewart, Alexander. “'Funky Drummer': New Orleans, James Brown and the Rhythmic Transformation of American Popular Music." In Popular Music 19, no. 3 (2000): 293-318.

. "Second Line." In Continuum Encyclopedia of Popular Music of the World, Performance and Production (Vol. 11) Edited by John Shepherd and David Horn et al. London: Bloomsbury: 620-623.

Veal, Michael E. Fela: The Life and Times of an African Musical Icon. Philadephia: Temple University Press, 2000.

Waterman, Christopher A. Jùjú: A Social History and Ethnography of an African Popular Music. Chicago: University of Chicago Press, 1990.

Williamson, Nigel. "Tony Allen: The Veteran Afrobeat Drummer Is Shaking His Sticks as Hard and as Brilliantly as Ever." The Independent, January 18, 2008. http://www.independent.co.uk/arts-entertainment/music/features/ tony-allen-the-veteran-afrobeat-drummer-is-shaking-his-sticks-as-hard-andas-brilliantly-as-ever-770993.html Accessed online July 29, 2012.

\section{Discography}

Afro-Rock (Volume 1): A Collection of Rare and Unreleased Afro-Beat Quarried from Across the Continent. Various artists. Kona Records STRUT059CD. 2010.

Africafunk: The Original Sound of 1970s Funky Africa. Various artists. Hurt CD 016. 1998.

Fela: The Complete Works of Fela Anikulapo Kuti (27-disc box set). Wrasse Records WRSS 271, 272, 273. 2010. (Does not include many early tracks heard on Lagos Baby.) 
118 Alexander Stewart

Heavy Heavy Heavy. Geraldo Pino and the Heartbeats. Retroafric RETRO20CD. 2005.

Lagos Baby: 1963-1969. Fela Ransome-Kuti. Vampisoul CD 097. n.d.

Star Time. James Brown. Box set. Polydor 849 108-2. 1991. 